\title{
Effect of Veneer Treatment with Phenol Formaldehyde on Dimensional Stability and Mechanical Properties of Oil Palm Stem (OPS) Plywood
}

\author{
Hasmawi Khalid, Zakiah Ahmad, Paridah Md. Tahir, and Jamaludin Kasim
}

\begin{abstract}
The main obstacle of oil palm stem (OPS) as a material for plywood manufacturing is the material that comes from a monocotyledon plant, which means that the material is not really a wood as what the wood-based industries have been used to. OPS are made up of parenchyma and vascular bundles. Fibres that are supposed to make up the strength are less and irregular in characteristic as compared to the 'dicotyledonous' wood. Due to its nature there is an extensive variation in moisture contents and basic density values at different part of OPS. This paper reports the investigation made on the effect of veneer treatment with phenol formaldehyde on dimensional stability and mechanical properties of oil palm stem plywood namely thickness swelling, water absorption, compression and panel shear. Four sources of plywood were used in this study. Type $A$ and $B$ were commercial oil palm plywood from 2 commercial factories. This plywood was using tropical veneer for its face and back layer. Type $C$ was tropical plywood while Type D was $100 \%$ oil palm plywood using veneer treatment with phenol formaldehyde. The results showed that plywood Type $D$ has lowest water absorption and highest value of compression and panel shear strength. Whereas plywood Type B exhibited lowest thickness swelling.
\end{abstract}

Index Terms-Mechanical properties, oil palm stem plywood, thickness swelling, water absorption.

\section{INTRODUCTION}

Nowadays most of the plywood industries are using tropical hardwood veneer to form plywood. As to reduce dependency on the tropical hardwood veneer, the inner layer can be manufactured using timber plantations species such as rubberwood or oil palm waste. Since rubberwood is also difficult to meet the demand in plywood industries, oil palm waste from oil palm stem (OPS) that are left behind after cutting process should be explored for plywood manufacturing.

Unlike rubberwood, the main obstacle for using OPS is that the OPS comes from a monocotyledon plant, which means that the material is not really a wood as what the

Manuscript received May 29, 2013; revised July 10, 2013

Hasmawi Khalid and Zakiah Ahmad are with Institute Infrastructure Engineering and Sustainable Management (IIESM), UniversitiTeknologi MARA, Malaysia, 40450 Shah Alam, Selangor (e-mail: hasmawiky@gmail.com).

Paridah Md. Tahir is with Institute of Tropical Forestry and Timber Product (INTROP), Universiti Putra Malaysia, 43400 Serdang, Selangor DarulEhsan.

JamaludinKasim is with Faculty of Applied Sciences, UniversitiTeknologi MARA (UiTM) Malaysia, 26400 Bandar PusatJengka, Pahang DarulMakmur. wood-based industries have been used to. Considering physical and mechanical properties of OPS, one can classify it as an 'inferior' lignocellulosic material, since OPSis made up of parenchyma and vascular bundles. The fibers that are supposed to make up the strength are less and irregular in characteristic as compared to the 'dicotyledonous' wood. Only the outer part of the trunk that contains fiber bundle as the centre part contains mostly soft parenchyma tissues. Due to its hygroscopic in nature, it shrinks and swells at higher rate than wood [1]. In addition there is an extensive variation in moisture contents and basic density values at different part of OPT itself [2]. Most of the highest mechanical properties of the oil palm stem were found to be approximately two times lower than the values obtained from teak and rubberwood [3].This problem may be associated with the cell wall structure and density variation inside the trunk [2]. The hardwood species that peelable for plywood production are generally have low permeability and are particularly difficult to dry quickly without degradation and distortion after drying. These problems can significantly reduced commercial recovery rates for many species as well as oil palm stem with an average recovery of $24 \%$ for the butt logs and only $6 \%$ for the top logs[4].Many species exhibit poor preservatives uptake and similarly for OPS. In order to overcome this problem OPS need to be impregnated with low molecular weight phenol formaldehyde (LmwPF) to improve its permeability and preservative uptake [5].

Plywood commonly used for formwork in construction, therefore it has to have good structural properties and resistant to moisture absorption. Therefore the top and bottom layer will be laminated with higher grade of tropical hardwood veneer. Combination of core OPS with top and bottom layer of tropical hardwood veneer will gives the problem in bond ability. It will affect shear performance under loading and mechanical properties. This study investigated the effect of veneer treatment with medium molecular weight phenol formaldehyde (MmwPF) on dimensional stability and mechanical properties of OPS Plywood.

\section{MATERIALS AND MethODS}

\section{A. Materials}

\section{1) Adhesive}

Medium molecular weight phenol formaldehyde (MmwPF) was supplied by the Malayan Adhesive \& Chemical Sdn. Bhd., Shah Alam, Selangor. 


\section{2) Veneer}

Oil palm stem (OPS) veneer was supplied by Central Kedah Plywood Sdn. Bhd., SungaiPetani, Kedah.

\section{3) Plywood}

Four sources of plywood were used in this study. Type A and $\mathrm{B}$ were commercial oil palm plywood from two commercial factories. This plywood used tropical veneer for its face and back layer. Type $\mathrm{C}$ was tropical plywood while Type D is the plywood prepared by the author using $100 \%$ oil palm plywoodwith the veneers treated with phenol formaldehyde.

\section{B. Preparation of $100 \%$ Oil Palm Plywoods (Type D)}

Three pieces of outer OPS veneers with thickness between $4.5-6.0 \mathrm{~mm}$ were cut to the dimensions of $4 \times 3$ feet. The veneer was then feed into roller pressing machine with the gap of the roller; $\mathrm{R}_{1}: \mathrm{R}_{2}: \mathrm{R}_{3}=3.5: 2.8: 2.8 \mathrm{~mm}$ and speed of the roller was 8.0rpm to squeeze out the water. Then, the veneer passing through a continuous roller dryer with temperature at $150{ }^{\circ} \mathrm{C}$ and speed $450 \mathrm{rpm}$ for 1 hour until the final moisture content (MC) of the veneers were $0 \% \mathrm{MC}$. After that, Medium molecular weight phenol formaldehyde (MmwPF) with ratio 80:20 for resin and water respectively and solid content $49.1 \%$ was applied two times on the veneer through glue spreader in gluing process. Then these veneers undergoes plattern press machine for pre-curing process for 9 minutes with the temperature of the plate ranging between $90-140^{\circ} \mathrm{C}$. The targeted $\mathrm{MC}$ at this stage was between $6-20 \% \mathrm{MC}$. These veneers were combined together and subjected to heat and pressure in the hot press until the glue was cured to form plywood panels at a temperature $115^{\circ} \mathrm{C}$ and pressure $120 \mathrm{~kg} / \mathrm{cm}^{3}$ for 15 minutes. After curing the boards are ready to be used. Fig. lillustrated the four type of plywood used in this study.

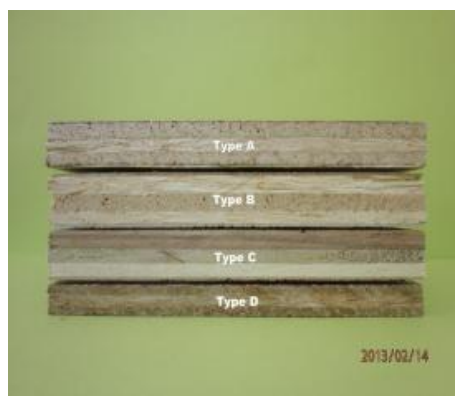

Fig. 1. Plywood Type A, B, C and D.

\section{Sample Reparation and Test Methods}

\section{1) Thickness swelling and water absorption}

The samples were cut into size $50 \mathrm{~mm} \times 50 \mathrm{~mm}$ for thickness swelling and water absorption determination with 10 replicates per plywood types. Thickness swelling and water absorption was determined based on European Norm EN 317: 1993 standard [6]. The test pieces were immersed with their faces vertical in clean, still water, having a $\mathrm{pH}$ of $7 \pm 1$ and a temperature of $(20 \pm 1){ }^{\circ} \mathrm{C}$.

This temperature was maintained for 24 hours throughout the test period. During the test, the test pieces were place in the tub separated from each other and without touching the bottom and the sides of the water bath. The tub was also filled with water to cover the upper edges of the test pieces with at least $25 \mathrm{~mm}$ of water throughout the test. The water was changed after each test.

The rate of thickness swelling $(G t)$ of the specimens was calculated as percentages, using the following equation:

$$
G_{t}=\frac{t_{2}-t_{1}}{t_{1}} \times 100
$$

where

$t_{2}$ : Thickness of the test piece after immersion (mm)

$t_{1}$ : Thickness of the test pieces before immersion ( $\mathrm{mm}$ )

The rate of water absorption (A) of the specimens shall be calculated as percentages, using the following equation:

$$
A(\%)=\frac{m_{1}-m_{2}}{m_{2}} \times 100
$$

where

$m_{1}$ : weight of the test pieces after immersion $(\mathrm{g})$

$m_{2}$ : weight of the test pieces before immersion $(\mathrm{g})$

2) Compression

The compression test was carried out using rectangular strips with dimensions of $60 \mathrm{~mm} \times 20 \mathrm{~mm}$ with 12 replicates per plywood types. The compression test was performed according to British Standard BS 373:1957 [7] using a Shimadzu Universal Testing Machine, $50 \mathrm{kN}$. The resistance to compression has been determined in parallel to the longitudinal grain. The load has been applied to test piece in such a way that the loading plates approach each other at a rate of $3 \mathrm{~mm} / \mathrm{min}$. The compression strength (in $\mathrm{N} / \mathrm{mm}^{2}$ ), of each test piece, is calculated from the formula:

$$
\text { Compression }=\frac{P}{A}
$$

where

$P$ is the maximum load in Newton

$A$ is the cross sectional area

\section{3) Panel Shear}

Samples for panel shear tests were cut into rectangular strips with dimensions of approximately $255 \mathrm{~mm} \times 85 \mathrm{~mm}$ with 8 replicates per plywood types. The panel shear tests were performed according to JAS 1751:2008 standards [8]; using a Shimadzu Universal Testing Machine, $50 \mathrm{kNat}$ a crosshead speed of $2 \mathrm{~N} / \mathrm{mm}^{2} / \mathrm{min}$. Mean loading speed was monitored so that it wills not more than 2.0 MPa per minute or less. The maximum loading was measured and the panel shears strength (in $\mathrm{N} / \mathrm{mm}^{2}$ ), of each test piece was calculated, using the following formula:

$$
\text { PanelShearStrength }=P s / h l
$$

where

$h$ is the nominal thickness of test piece (mm)

$l$ is the length of test piece $(\mathrm{mm})$

$P s$ is the maximum load (N)

\section{RESULT AND DISCUSSION}

The physical and mechanical properties of plywood from four different sources were tested and evaluated. Table I shows the summary of the thickness swelling and water absorption of all plywood investigated. 
TABLE I: PHYSICAL PROPERTIES OF PLYWOOD

\begin{tabular}{|c|c|c|c|c|}
\hline Source & $\begin{array}{l}\text { Density } \\
\left(\mathrm{Kg} / \mathrm{m}^{3}\right)\end{array}$ & $\begin{array}{c}\text { Thickness } \\
(\mathrm{mm})\end{array}$ & $\begin{array}{c}\text { Thickness } \\
\text { Swelling } \\
(\%)\end{array}$ & $\begin{array}{c}\text { Water } \\
\text { Absorpti } \\
\text { on } \\
(\%)\end{array}$ \\
\hline \multirow{3}{*}{ A } & 792.38 & 10.62 & 3.77 & 49.82 \\
\hline & $41.71 *$ & $0.63 *$ & $0.88 *$ & $8.08 *$ \\
\hline & $5.26^{* *}$ & $5.96^{* *}$ & $23.40 * *$ & $16.23^{* *}$ \\
\hline \multirow{3}{*}{ B } & 551.33 & 12.23 & 2.10 & 57.67 \\
\hline & $9.89^{*}$ & $0.43^{*}$ & $0.60 *$ & $4.40 *$ \\
\hline & $1.79 * *$ & $3.50 * *$ & $28.35^{* *}$ & $7.64 * *$ \\
\hline \multirow{3}{*}{$\mathrm{C}$} & 524.36 & 11.97 & 4.13 & 49.96 \\
\hline & $71.24 *$ & $0.08 *$ & $0.87 *$ & $3.13^{*}$ \\
\hline & $13.59^{* * *}$ & $0.70 * *$ & $21.17 * *$ & $6.26^{* * *}$ \\
\hline \multirow{3}{*}{ D } & 685.69 & 7.77 & 10.59 & 45.68 \\
\hline & $39.79 *$ & $0.48 *$ & $1.85 *$ & $6.98 *$ \\
\hline & $5.80 * *$ & $6.22 * *$ & $17.51 * *$ & $15.29 * *$ \\
\hline
\end{tabular}

\section{A. Thickness Swelling}

From Table I, it can be seen that the thickness of the plywood used in this study are not the same. This because those plywood are commercial plywood's except for plywood Type D. Plywood Type B is thicker than Type A by $15.2 \%$, and higher than Type $\mathrm{C}$ by $(2.2 \%)$ and higher than Type D by $(57.4 \%)$

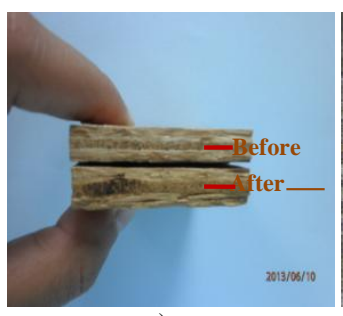

a)

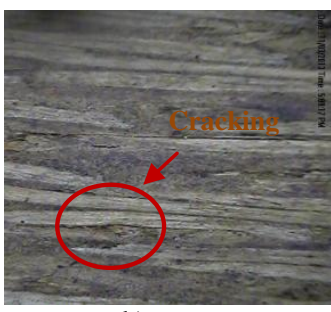

b)

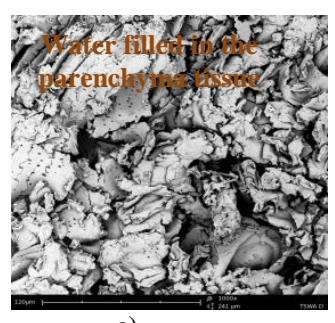

Fig. 2. a) Sample before and after immersion, b) View of sample after immersion by using stereo zoom microscope at 0.8 magnification and $\mathrm{c}$ ) SEM image of plywood Type D.

In reference to the thickness swelling, can be seen there are significant difference in the thickness swelling for plywood Type A, B, C and D. However the difference in the thickness swelling for plywood Type A, B and C are not that great as compared to the thickness swelling for plywood Type D. Plywood Type Dexhibited highest thickness swelling, followed by Type C, Type A and Type B.

As the thickness of the panel varied therefore the effect of treatment on the veneer for plywood Type D on the thickness swelling is for time being is difficult to conclude. Fig.2 a), illustrated the specimens before and after immersion. Physically there are not much different of the specimens between before and after immersion. Fig. 2 b), shows some parenchyma diffuse from the vascular bundles due to immersion in water for 24 hours. As can be seen in Fig. 2 c), water was filled in the parenchyma tissue after immersion.

\section{B. Water Absorption}

Table 1 shows the water absorption results of four sources of plywood. Overall plywood TypeB exhibited highest value of water absorption (57.67\%), followed by Type C (49.96\%), Type A $(49.82 \%)$ and lastly Type D (45.68\%). Plywood Type D exhibited lowest value in water absorption (45.68\%) and this finding was supported by Y.F Loh et al.[5] whereas after veneer was treated with low molecular weight phenol formaldehyde (LmwPF), the resin will bond together parenchyma tissue, cell wall and lumen for much uniform density (due to the phenolic resin) and better surface bonding.In addition H.P.S Abdul Khalil et al. [9] agreed that phenol formaldehyde (PF) will gives greater water resistance compared to urea formaldehyde (UF) due to higher methylene content and greater cross-linking density.

The relationship between the thickness of the plywood with thickness swelling and water absorption is further illustrated in Fig. 3. As the thickness of the plywood increased, the thickness swelling decrease and water absorption are independent of the types of plywood.

From Table I, it can also be seen that as the thickness increases, the density decreases which caused the high water absorption.

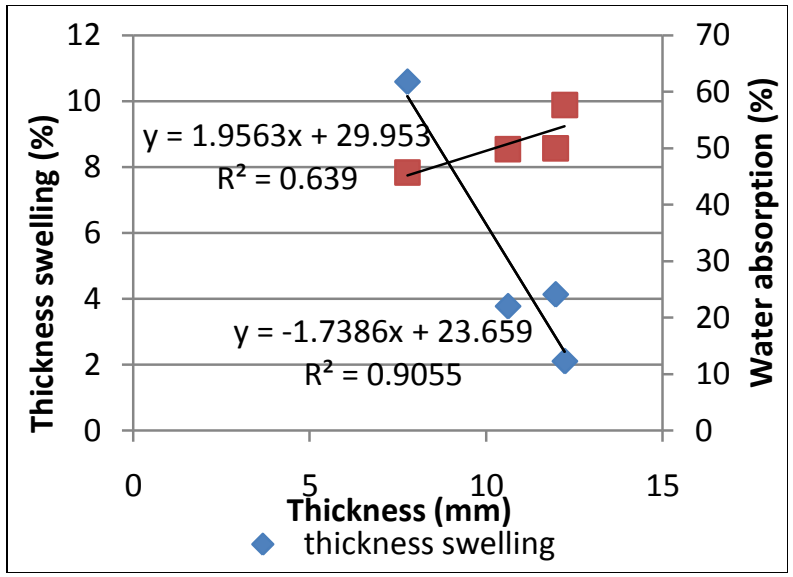

Fig. 3. Relationship between thickness of the plywood with thickness swelling and water absorption.

\section{Compression}

From Table II, the compression strength of plywood Type D exhibited highest strength value $\left(27.54 \mathrm{~N} / \mathrm{mm}^{2}\right)$ compared to other plywood; Type A $\left(8.99 \mathrm{~N} / \mathrm{mm}^{2}\right)$, Type B $(13.45$ $\left.\mathrm{N} / \mathrm{mm}^{2}\right)$ and Type $\mathrm{C}\left(26.03 \mathrm{~N} / \mathrm{mm}^{2}\right)$. The compressive strength of plywood Type D is the highest and it is $210.8 \%$ higher than Type A, 104\% higher than Type B and 5.8\% higher than Type $\mathrm{C}$.

Although plywood Type D has lowest in thickness (7.77 $\mathrm{mm})$ and moisture MC (8.32\%) compared to others, it is still performing better in compression. This result was supported by Y. B. Hoong et al.[10] which indicated that the plywood treated with LmwPF resin clearly shows that of at least $200 \%$ stronger, $259 \%$ stiffer in terms of strength, improvement dimensional stability (6\% thickness swelling and $36 \%$ water 
absorption) as well as, $28 \%$ (dry test) and $80 \%$ (WBP test) greater in bonding strength, respectively than the commercial OPS plywood.

\begin{tabular}{|c|c|c|c|c|}
\hline Source & $\begin{array}{l}\text { M.C } \\
(\%)\end{array}$ & $\begin{array}{l}\text { Density } \\
\left(\mathrm{kg} / \mathrm{m}^{3}\right)\end{array}$ & $\begin{array}{c}\text { Compression } \\
\text { Strength } \\
\left(\mathrm{N} / \mathrm{mm}^{2}\right)\end{array}$ & $\begin{array}{c}\text { Panel } \\
\text { Shear } \\
\left(\mathrm{N} / \mathrm{mm}^{2}\right)\end{array}$ \\
\hline \multirow{3}{*}{ A } & 13.07 & 792.38 & 8.99 & 4.68 \\
\hline & $0.57^{*}$ & $41.71^{*}$ & $1.10^{*}$ & $1.25^{*}$ \\
\hline & $4.35^{* * *}$ & $5.26^{* *}$ & $12.25^{* * *}$ & $26.79 * *$ \\
\hline \multirow{3}{*}{ B } & 11.85 & 551.33 & 13.45 & 3.44 \\
\hline & $0.39 *$ & $9.89^{*}$ & $1.62 *$ & $0.70^{*}$ \\
\hline & $3.29 * *$ & $1.79 * *$ & $12.03^{* * *}$ & $20.25 * *$ \\
\hline \multirow{3}{*}{$\mathrm{C}$} & 10.79 & 524.36 & 26.03 & 7.24 \\
\hline & $0.24 *$ & $71.24 *$ & $1.09^{*}$ & $0.70^{*}$ \\
\hline & $2.18^{* *}$ & $13.59^{* * *}$ & $4.19 * *$ & $9.72 * *$ \\
\hline \multirow{3}{*}{ D } & 8.32 & 685.69 & 27.54 & 8.73 \\
\hline & $1.06^{*}$ & $39.79^{*}$ & $1.79^{*}$ & $1.26^{*}$ \\
\hline & $12.76^{* *}$ & $5.80^{* * *}$ & $6.49 * *$ & $14.41^{* *}$ \\
\hline
\end{tabular}

Fig. 4 a) illustrated failure mode of OPS plywood loaded in compression. Most of the failure is classified asbrooming and splitting. Generally, the failure was generated attop and bottom section, both in tangential and radial surface caused by loading direction. Fig. 4 b) and Fig. 4 c) illustrated failure mood in compression both in stereo zoom microscope and scanning electron microscopic (SEM) respectively.

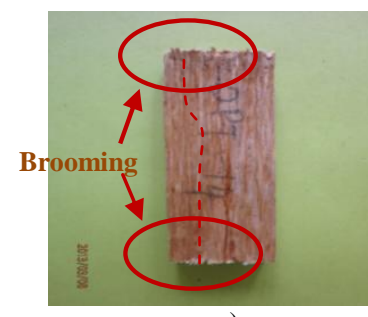

a)

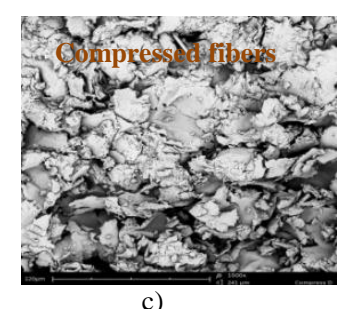

c)

Fig. 4. a) Wood failure in compression parallel to the grain, b) Stereo zoom microscope at 0.8 magnification for wood failure in compression and c) SEM photo of wood failure in compression at 1000x.

\section{Panel Shear}

From Table II, the panel shear strength of plywood Type D again exhibited highest panel shear strength value $(8.73$ $\mathrm{N} / \mathrm{mm}^{2}$ ) compared to other plywood from Type A (4.68 $\left.\mathrm{N} / \mathrm{mm}^{2}\right)$, Type B $\left(3.44 \mathrm{~N} / \mathrm{mm}^{2}\right)$ and Type C $\left(7.24 \mathrm{~N} / \mathrm{mm}^{2}\right)$. Plywood Type D is highest than Plywood Type A by $86.5 \%$, Type B (153.8\%) and Type C (20.6\%). There are high variations in the Type A plywood for Coefficient of Variance (CoV26.79\%) compared with Type B (CoV
20.25\%), Type D (CoV 14.41\%) and Type C (CoV 9.72\%).

Fig. 5 a) illustrated failure mode of OPS plywood in panel shear. Fig. 5 b) and Fig. c) illustrated failure mood in panel shear in stereo zoom microscope at 0.8 magnification and scanning electron microscopic (SEM) respectively. Most of the failure is classified in Middle Splitting. Generally, the failure was generated in the middle section of specimen in both radial and tangential surfaces in the loading direction.

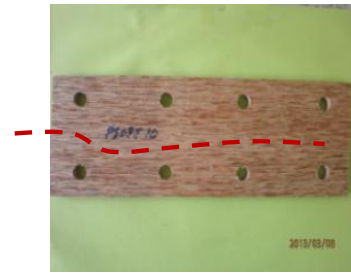

a)

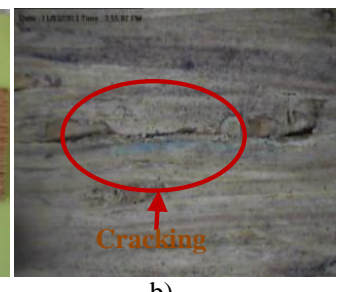

b)

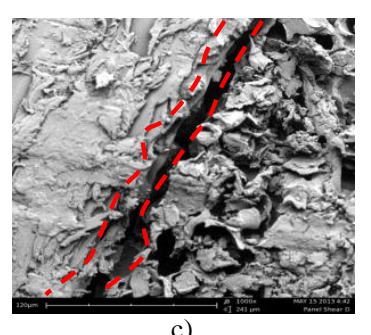

c)

Fig. 5. a) Wood failure in panel shear, b) Stereo zoom microscope at 0.8 magnification for wood failure in panel shear and c) SEM photo of wood failure in panel shear at 1000x.

\section{ACKNOWLEDGMENT}

The authors would like to express greatest appreciation and gratitude to the UniversitiTeknologi MARA of Malaysia (UiTM), Universiti Putra of Malaysia (UPM) and Malaysian Timber Industrial Boards (MTIB) for assisting and funding this study. Thanks are also rendered to Plus IntervestSdn. Bhd and Central Kedah Plywood Industry Sdn. Bhd. for supplying OPS Plywood and processing facalities and Malayan Adhesive and Chemicals (M) Sdn. Bhd. for providing the MmwPF resins.

\section{REFERENCES}

[1] S. C. Lim and K. C. Khoo, "Characteristics of oil palm trunkand its potential utilization," TheMalaysian Forester, vol. 49, no. 1, pp. 322, 1986.

[2] A. C. Y. Choo et al., "Density and humidity gradient inveneers of oil palm stems," European Journalof wood and woodproducts, vol. 69, no. 3 , pp. 501-503, 2010.

[3] T. Ranatawilai, T. Chumthong, and S. Kirdkong, "An investigating on the mechanicalproperties of trunks of palm oiltrees for furniture industry," Journal of Oil Palm Research, pp. 114-121, 2006.

[4] K. C. KhozirahShaari et al., "Oil palm utilization review of research," Research pamphlet, no.107, 1991.

[5] A. C. C. Yoong et al., "Effect of treatment with low molecular weight phenol formaldehyde resin on the surface characteristics of oil palm (ElaisQuineensis) stem veneer," Materials and Design, vol. 32, pp. 2277-2283, 2011.

[6] Particleboards and fibreboards-Determination of swelling inthickness after immersion in water, European Norm EN317, 1993.

[7] Method of testing small clear specimens, British Standard BS373, 1957.

[8] Japanese agricultural standard for plywood, JAS 1751, 2008.

[9] H. P. S. A. Khalil et al., "Development and materials properties of new hybrid plywood from oil palm biomass," Journal Materials and Design, vol. 31, pp. 417-424, 2010.

[10] Y. B. Hoong et al., "Development of a new pilot scale production of high grade oil palm plywood: Effect of pressing pressure," Journal of Material and Design, vol. 36, 2012, pp. 215-219. 


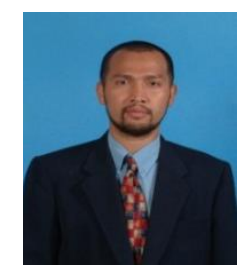

Hasmawi Khalid was born at Bentong, Pahang, Malaysia on $30^{\text {th }}$ June 1977 . He received his Diploma in wood TECHNOLOGY from Institut Teknologi MARA, Shah Alam, Selangor, Malaysia on 1998. After that he pursue his study inBachelor of Science Furniture Manufacturing from UniversitiTeknologi MARA, Shah Alam, Selangor by the year 2002. In 2003 he got his Master in Education (Technical and Vocational) from Kolej Universiti Teknologi TunHussienOnn, BatuPahat, Johor.

He worked as a lecturer in KolejKomunitiTemerloh from July 2003 until June 2010. His last post was Student Affair Officer before he continued his study in Degree in Philosophy (Civil Engineering) from June 2010 until recently. His research interest is more on structure and materials, timber engineering, bio-composite and conversion of agro industrial wastes into value added products. Currently his working on development of plywood from oil palm stem.

Mr Hasmawi Khalid is a member of Malaysian Nature Society and Malaysian Scientific Associations. He received Best worker award of Polytechnics and Community College Studies Department, Ministry of Higher Education, Malaysia, 2007.

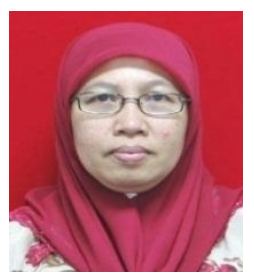

Zakiah Ahmad received her bachelor of sciences in civil engineering, Memphis State University, USA on December 1985. After that she got her Master in Statistics, University of Memphis, USA on Dec 1994 and $\mathrm{PhD}$ from University of Bath on April 2000.

Her current academics responsibilities are as a Director of Institute Infrastructure Engineering and Sustainable Management (IIESM),

UniversitiTeknologi MARA, Malaysia. Her research interest are wood polymer composites, composite from renewable raw materials, polymer based nanocomposite, adhesive-timber connections/joints, timber engineering and bonded-in timber connection.
Associate Prof Dr Zakiah Ahmad is a Member of Board of Engineers Malaysia (BEM), Member of International Associational Association of Concrete Technology and Member of Malaysian Forest Product Association.

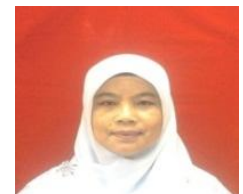

Paridah Md. Tahir has her diploma in forestry from UniversitiPertanian Malaysia on 1980 and got her Bachelor of Sciences in Wood Science and Technology, Mississippi State University, Mississippi State, USA on 1987. After that she got her Master in Wood Adhesive, Mississippi State University, Mississippi State, USA on 1989 and PhD in Wood Chemistry from University of Aberdeen, Scotland on

1995.

Professor Paridah Md. Tahir current academics responsibilities areas a Director of Institute of Tropical Forestry and Timber Product (INTROP), Universiti Putra Malaysia. Her research interests are applied sciences and technology, wood adhesive and biocomposite material, wood bonding and product performance.

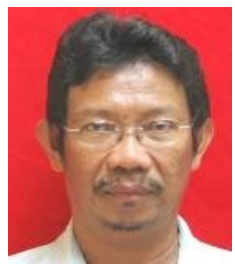

Jamaludin Kasim got his diploma in wood technology from InstitutTeknologi MARA, Malaysia on 1979 then got his Master of Forestry in Wood Science and Technology from University of Philippinesat Los Banos on 1984. After that he got his $\mathrm{PhD}$ in Wood Science \& Technology from Universiti Putra Malaysia on 2000.

Professor JamaludinKasim current academics responsibilities are as a Head of Faculty of Applied Sciences (Wood Industry) UniversitiTeknologi MARA, Pahang, Malaysia. His research interests are materials processing technology, wood and non wood-based forest products, forest products, polymer composites and biomaterials. 